\title{
Occupational health guidelines for the management of low back pain: an international comparison
}

\author{
J B Staal, H Hlobil, M W van Tulder, G Waddell, A K Burton, B W Koes, W van \\ Mechelen
}

Occup Environ Med 2003;60:61 8-626 See end of article for
authors' affiliations

\section{Correspondence to:} Prof. W van Mechelen, Department of Social

Medicine, Institute for Research in Extramural Medicine, VU University Medical Center, 1081 BT

Amsterdam, Netherlands; w.van_mechelen.emgo@med. vu.nl

Accepted

7 November 2002
Background: The enormous socioeconomic burden of low back pain emphasises the need for effective management of this problem, especially in an occupational context. To address this, occupational guidelines have been issued in various countries.

Aims: To compare available international guidelines dealing with the management of low back pain in an occupational health care setting.

Methods: The guidelines were compared regarding generally accepted quality criteria using the AGREE instrument, and also summarised regarding the guideline committee, the presentation, the target group, and assessment and management recommendations (that is, advice, return to work strategy, and treatment).

Results and Conclusions: The results show that the quality criteria were variously met by the guidelines. Common flaws concerned the absence of proper external reviewing in the development process, lack of attention to organisational barriers and cost implications, and lack of information on the extent to which editors and developers were independent. There was general agreement on numerous issues fundamental to occupational health management of back pain. The assessment recommendations consisted of diagnostic triage, screening for "red flags" and neurological problems, and the identification of potential psychosocial and workplace barriers for recovery. The guidelines also agreed on advice that low back pain is a self limiting condition and, importantly, that remaining at work or an early (gradual) return to work, if necessary with modified duties, should be encouraged and supported.
 ow back pain (LBP) is one of the most common health problems in industrial countries. Despite its benign nature and favourable course, LBP is commonly associated with incapacity, productivity loss due to sick leave, and corresponding high costs to the society. ${ }^{1}$

In view of that impact, there is an obvious need for effective management strategies, based on scientific evidence derived from studies of sound methodological quality. Usually, these are randomised controlled trials (RCTs) on the effectiveness of therapeutic interventions, diagnostic studies, or prospective observational studies on risk factors or side effects. The scientific evidence, which is summarised in systematic reviews and meta-analyses, provides a solid basis for guidelines on the management of LBP. In a previous paper, Koes et al compared various existing clinical guidelines for the management of LBP

\section{Main messages}

- In various countries occupational health guidelines are issued to improve the management of low back pain in an occupational context.

- Common flaws of these guidelines concern the absence of proper external reviewing in the development process, lack of attention to organisational barriers and cost implications, and lack of information on the independence of editors and developers.

- In general the assessment recommendations in the guidelines consisted of diagnostic triage, screening for "red flags" and neurological problems, and the identification of potential psychosocial and workplace barriers for recovery.

- There is general agreement on advice that low back pain is a self limiting condition and that remaining at work or an early (gradual) return to work, if necessary with modified duties, should be encouraged and supported. targeted at primary health care professionals, which showed a large measure of commonality. ${ }^{2}$

However, LBP is also an important issue in occupational health care because of the associated incapacity for work, productivity loss, and sick leave. The problems in the field of occupational health care are different and management focuses mainly on counselling the worker with LBP, and addressing the issues of assisting him or her to continue working, or to return to work (RTW) after sick listing. Several guidelines, or sections of guidelines, have now been published dealing with the specific issues of management in an occupational health care setting. Since the evidence is international, it would be expected that the recommendations of different occupational guidelines for LBP would be more or less similar. However, it is not clear whether the guidelines meet currently accepted quality criteria.

This paper critically appraises available occupational guidelines on the management of LBP, and compares their assessment and management recommendations.

\section{METHODS}

Guidelines on the occupational health management of LBP were retrieved from personal files of the authors. Retrieval was checked by a Medline search using the keywords "low back pain", "guidelines", and "occupational" up to October 2001, and personal communication with experts in the field. Guidelines had to meet the following inclusion criteria:

Abbreviations: LBP, low back pain; RCT, randomised controlled trial; RTW, return to work 


\section{Policy implications}

- The management of low back pain in occupational health care should be in accordance with the recommendations of evidence based guidelines.

- Future occupational guidelines for the management of low back pain and updates of those guidelines should consider the criteria for proper development, implementation, and evaluation of guidelines as suggested by the AGREE collaboration.

- Guidelines aimed at the management of workers with LBP (in occupational health care settings or addressing occupational issues), or separate sections of guidelines that dealt with these topics.

- Guidelines available in English or Dutch (or translated into these languages).

The exclusion criteria were:

- Guidelines on primary prevention (that is, prevention before the onset of the symptoms) of work related LBP (for example, lifting instructions for workers).

- Clinical guidelines for the management of LBP in primary care. $^{2}$

The quality of the included guidelines was appraised using the AGREE instrument, which is a generic tool designed primarily to help guideline developers and users assess the methodological quality of clinical practice guidelines. ${ }^{3}$

The AGREE instrument provides a framework for the assessment of quality on 24 items (table 1), each rated on a four point scale. The full operationalisation is available on www.agreecollaboration.org.

Two reviewers (BS and $\mathrm{HH}$ ) independently rated the quality of the guidelines, and then met to discuss disagreements and to reach consensus on the ratings. When they could not reach consensus, a third reviewer $(\mathrm{MvT})$ reconciled remaining differences and made a final decision on the ratings. To facilitate analysis in this review, ratings were transformed into dichotomous variables of whether each quality item was or was not met.

The selected guidelines were further characterised and compared regarding the guideline committee, the presentation of the guideline, the target group, and the extent to which the recommendations were based on available scientific evidence. The assessment recommendations were also summarised and compared, as were recommendations on advice, treatment, and return to work strategies. All of this information was extracted directly from the published guidelines.

\section{RESULTS}

\section{Selection of studies}

Our search found 10 guidelines, ${ }^{4-18}$ but four were excluded because they dealt with the management of LBP in primary care, ${ }^{15}$ were aimed at the guidance of sick listed employees in general (not specifically LBP), ${ }^{16}$ were intended for the primary prevention of LBP at work, ${ }^{17}$ or were not available in English or Dutch. $^{18}$ The final selection therefore consisted of the following six guidelines, listed by date of issue:

(1) Canada (Quebec). Scientific approach to the assessment and management of activity related spinal disorders. A monograph for clinicians. Report of the Quebec Task Force on Spinal Disorders. Quebec Canada (1987). ${ }^{4}$

(2) Australia (Victoria). Guidelines for the management of employees with compensable low back pain. Victorian WorkCover Authority, Australia (1996). ${ }^{5}$ (This guideline is a revised version of guidelines developed by the South Australian WorkCover Corporation in October 1993.)
(3) USA. Occupational Medicine Practice Guidelines. American College of Occupational and Environmental Medicine. USA (1997). ${ }^{6}$

(4) New Zealand

(a) Active and working! Managing acute low back pain in the workplace. Accident Compensation Corporation and National Health Committee. New Zealand (2000). ${ }^{7}$

(b) Patient guide to acute low back pain management. Accident Compensation Corporation and National Health Committee. New Zealand (1998). ${ }^{8}$

(c) Guide to assessing psychosocial yellow flags in acute low back pain. Accident Compensation Corporation and National Health Committee. New Zealand (1997). ${ }^{9}$

(5) Netherlands. Dutch guideline for the management of occupational physicians of employees with low back pain. Dutch Association of Occupational Medicine (NVAB). Netherlands (1999). ${ }^{10}$

(6) UK

(a) Occupational health guidelines for the management of low back pain at work-principal recommendations. Faculty of Occupational Medicine. UK (2000). ${ }^{11}$

(b) Occupational health guidelines for the management of low back pain at work-leaflet for practitioners. Faculty of Occupational Medicine. UK (2000). ${ }^{12}$

(c) Occupational health guidelines for the management of low back pain at work-evidence review. Faculty of Occupational Medicine. UK (2000). ${ }^{13}$

(d) The Back Book, The Stationery Office. UK (1996). ${ }^{14}$

Two guidelines ( 4 and 6 ) could not be evaluated independently from additional documents to which they refer $(4 \mathrm{~b}-\mathrm{c}, 6 \mathrm{~b}-\mathrm{d})$ so these documents were also included in the review.

\section{Appraisal of the quality of the guidelines}

Initially, there was agreement between the two reviewers regarding 106 (77\%) of the 138 item ratings. After two meetings, consensus was reached for all but four items, which required adjudication by the third reviewer. Table 1 presents the final ratings.

All included guidelines clearly presented the different options for the management of LBP in occupational health. In five of the six guidelines the overall objectives of the guideline were described specifically, ${ }^{4-6}{ }^{10-14}$ the target users of the guideline were clearly defined, ${ }^{5-14}$ easily identifiable key recommendations were included, ${ }^{4-14}$ or key review criteria were presented for monitoring and/or audit purposes. ${ }^{4-9}{ }^{11-14}$

The results of the AGREE appraisal showed that none of the guidelines paid sufficient attention to potential organisational barriers and cost implications in implementing the recommendations. It was also unclear for all included guidelines whether or not they were editorially independent from the funding body, and whether or not there were conflicts of interest for the members of the guideline development committees. Furthermore, it was unclear for all guidelines whether experts had externally reviewed the guidelines prior to publication. Only the UK guideline clearly described the method used for the formulation of the recommendations, and provided for updating the guideline. ${ }^{11}$

\section{Development of the guidelines}

Table 2 presents background information on the development process of the guidelines.

The target users for the guidelines were physicians and other health care providers in the field of occupational health care. Several guidelines were also directed at informing 


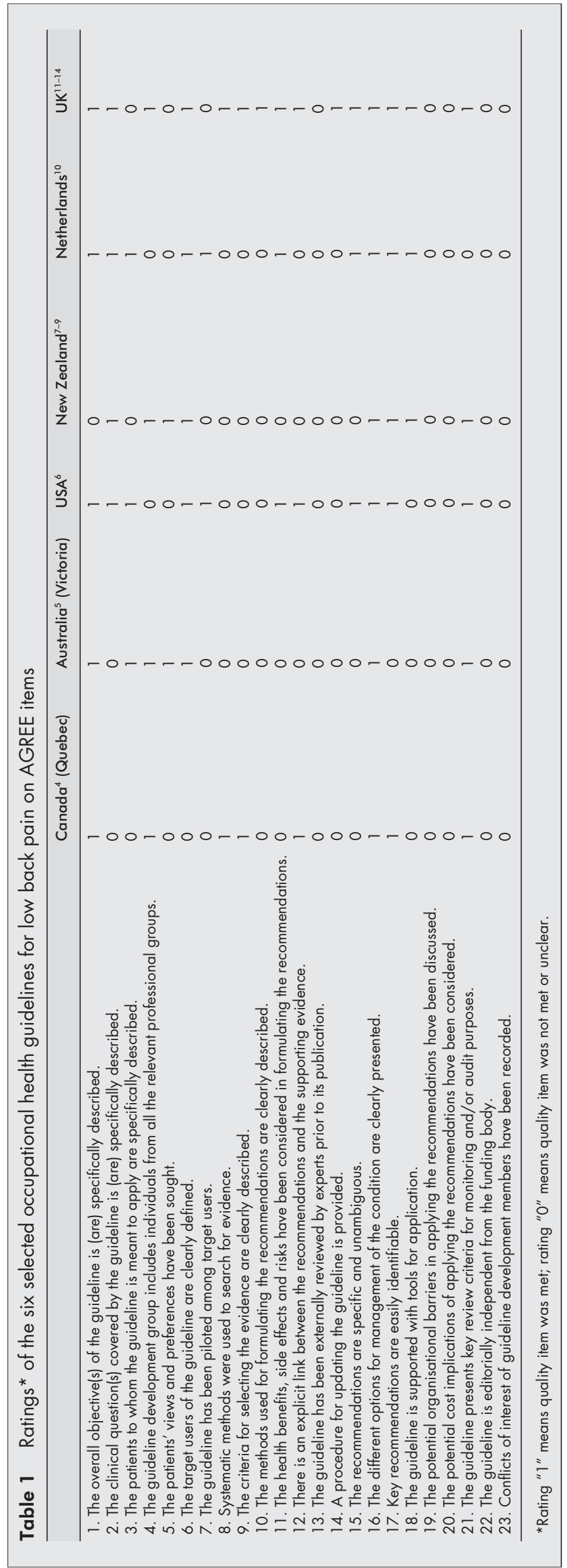

employers, workers, ${ }^{6-811} 14$ or members of organisations interested in occupational health. ${ }^{4}$ The Dutch guideline was only targeted at the occupational health physician. ${ }^{10}$

The guideline committees responsible for the development of the guidelines were generally multidisciplinary, including disciplines like epidemiology, ergonomics, physiotherapy, general practice, occupational medicine, occupational therapy, orthopaedics, and representatives of employers' associations and trade unions. Chiropractic and osteopathic representatives were in the guideline committee of the New Zealand guidelines..$^{7-9}$ The Quebec task force (Canada) also included representatives of rehabilitation medicine, rheumatology, health economics, law, neurosurgery, biomechanical engineering, and library sciences. In contrast, the guideline committee of the Dutch guideline consisted only of occupational physicians. ${ }^{10}$

The guidelines were issued as a separate document, ${ }^{45}{ }^{10}$ as a chapter in a textbook, ${ }^{6}$ or as several interrelated documents. ${ }^{7-9} 11-14$

The UK, ${ }^{13}$ USA, $^{6}$ and Canadian ${ }^{4}$ guidelines provided information on the search strategy applied to the identification of relevant literature and the weighing of the evidence. On the other hand, the Dutch ${ }^{10}$ and the Australian ${ }^{5}$ guidelines supported their recommendations only by references. In the New Zealand guidelines there were no direct links between recommendations and references, ${ }^{7-9}$ and the reader was referred to other literature for background information.

\section{Patient population and diagnostic recommendations}

Despite the fact that all guidelines focused on workers with LBP, it was often not clear whether they dealt with acute or chronic LBP or both. Acute and chronic LBP were often not defined, and when cut off points were given (for example, $<3$ months) it was usually not clear whether these referred to the onset of symptoms or to absence from work. However, the Canadian guideline introduced a classification system (acute/subacute/ chronic) based on the distribution of claims of spinal disorders by time since absence from work. ${ }^{4}$

All guidelines distinguished specific and non-specific LBP. Specific LBP concerns the potentially serious "red flag" conditions like fractures, tumours, or infections, and the Dutch and UK guidelines also distinguished the radicular syndrome or nerve root pain. ${ }^{10-13}$ All guidelines were consistent in their recommendations to take a clinical history and to carry out a physical examination including neurological screening. In cases of suspected specific pathology ("red flags"), $x$ ray examinations were recommended by most guidelines. In addition, the New Zealand and the US guideline also recommended $x$ ray examination when symptoms did not improve after four weeks. ${ }^{69}$ The UK guideline stated that $x$ ray examinations are not indicated and do not assist occupational health management of the patient with LBP (as distinct from any clinical indications). ${ }^{11-13}$

Most of the guidelines considered psychosocial factors-"yellow flags"-as obstacles to recovery that should be addressed by health care providers. The New Zealand ${ }^{9}$ and UK guideline ${ }^{11} 12$ explicitly listed factors and suggested questions in order to identify those psychosocial "yellow flags".

All guidelines addressed the importance of the clinical history identifying physical and psychosocial workplace factors relevant to LBP, including physical demands of work (manual handling, lifting, bending, twisting, and 
Table 2 Background information related to the development of the guidelines

\begin{tabular}{|c|c|c|c|c|}
\hline Country & Guideline Committee & Target group & Presentation & Evidence base \\
\hline Canada (Quebec) & $\begin{array}{l}\text { Multidisciplinary: Epidemiology, Community Medicine, } \\
\text { Rehabilitation, Physical Therapy, Rheumatology, Health } \\
\text { Economics, Orthopaedics, Law, Occupational } \\
\text { Medicine, Neurosurgery, Occupational Therapy, } \\
\text { Biomechanical Engineering, Ergonomics, Biostatistics, } \\
\text { library Sciences. }\end{array}$ & $\begin{array}{l}\text { Health care professionals, professionals in } \\
\text { allied fields who assess and treat disabled } \\
\text { workers, members of organisations } \\
\text { interested } \\
\text { in occupational health and safety. }\end{array}$ & Report: publication in journal. ${ }^{4}$ & $\begin{array}{l}\text { Comprehensive literature search, weighing of the evidence } \\
\text { based on type and quality of studies. }\end{array}$ \\
\hline Australia (Victoria) & $\begin{array}{l}\text { Multidisciplinary: Orthopaedics, Rehabilitation } \\
\text { Medicine, Workers compensation management, } \\
\text { Representative of union of workers, General practice. }\end{array}$ & $\begin{array}{l}\text { Practitioners managing } \\
\text { work related LBP. }\end{array}$ & $\begin{array}{l}\text { Guideline document: guideline is a revised } \\
\text { version of guidelines developed by the } \\
\text { South Australian WorkCover Corporation } \\
\text { in October } 1993 \text {. }\end{array}$ & $\begin{array}{l}\text { Recommendations supported by references or based on } \\
\text { consensus and common practice, no explicit weighing of } \\
\text { evidence. }\end{array}$ \\
\hline USA & $\begin{array}{l}\text { Developed by the American College of Occupational } \\
\text { and Environmental Medicine. }\end{array}$ & $\begin{array}{l}\text { Physicians and other health care providers, } \\
\text { consumers } \\
\text { in occupational health. }\end{array}$ & $\begin{array}{l}\text { Publication in a book of guidelines for } \\
\text { (mainly) musculoskeletal complaints. }\end{array}$ & $\begin{array}{l}\text { Comprehensive literature search, weighing of the evidence } \\
\text { based on number and quality of studies, use of consensus } \\
\text { in case of absence of evidence. }\end{array}$ \\
\hline New Zealand & $\begin{array}{l}\text { Multidisciplinary: Physiotherapy, General practice, } \\
\text { Osteopathy, Chiropractic, Occupational Therapy, } \\
\text { Ergonomics, Orthopaedics, Representatives of } \\
\text { employers' associations and trade unions. }\end{array}$ & Employer, worker, treatment providers. & $\begin{array}{l}\text { Separate guidelines for the management } \\
\text { of LBP in the workplace, and for the } \\
\text { assessment of psychosocial "yellow flags". } \\
\text { Patient booklet. }\end{array}$ & $\begin{array}{l}\text { There is no information in either guideline on search } \\
\text { strategies and there are hardly any links between } \\
\text { recommendations and references. Management } \\
\text { suggestions outlined in the "yellow flags" guideline are } \\
\text { reported to be based on the best available evidence to } \\
\text { date." }\end{array}$ \\
\hline Netherlands & Single discipline: occupational physicians. & Occupational physicians. & Guideline document. & $\begin{array}{l}\text { Recommendations supported by references or based on } \\
\text { consensus, no explicit weighing of evidence. }\end{array}$ \\
\hline UK & $\begin{array}{l}\text { Multidisciplinary: Occupational Medicine, } \\
\text { Orthopaedics, Ergonomics, Physiotherapy, } \\
\text { General Practice, Nursing, Government policy, } \\
\text { Scientific adviser. }\end{array}$ & Occupational health practitioners. & $\begin{array}{l}\text { Guideline documents, }{ }^{11} \text { evidence review, }{ }^{13} \\
\text { leaflet } \\
\text { for practitioners, }{ }^{12} \text { separate guide for } \\
\text { people at work and employers, and } \\
\text { patient booklet (The Back Book). }{ }^{14}\end{array}$ & $\begin{array}{l}\text { Comprehensive literature search, weighing of the evidence } \\
\text { based on number and quality of studies ( } 3 \text {-star system), } \\
\text { recommendations directly linked to relevant studies, some } \\
\text { recommendations based on good practice (legally or by } \\
\text { consensus). }\end{array}$ \\
\hline
\end{tabular}


Table 3 Occupational guidelines: recommendations regarding assessment of LBP

\begin{tabular}{|c|c|c|c|c|c|c|}
\hline Country & Patient population & Diagnostic classification & Examination & $x$ ray examination & Psychosocial factors & Workplace factors \\
\hline $\begin{array}{l}\text { Canada } \\
\text { (Quebec) }\end{array}$ & $\begin{array}{l}\text { Subjects (workers) with } \\
\text { activity related spinal } \\
\text { disorders }\end{array}$ & $\begin{array}{l}11 \text { categories ranging from LBP } \\
\text { without radiation to chronic pain } \\
\text { syndrome and "other diagnoses". } \\
\text { Further classification of duration } \\
\text { (<7 days, } 7 \text { days-7 weeks, }>7 \\
\text { weeks) and working status } \\
\text { (working or idle); idle means } \\
\text { absent from work, unemployed or } \\
\text { inactive. }\end{array}$ & $\begin{array}{l}\text { 0-4 weeks absence from work: history and } \\
\text { complete physical examination (including } \\
\text { neurological examination); in case of serious } \\
\text { disease further investigation. } \\
4-7 \text { weeks absence from work: re-evaluation, } \\
\text { radiograph and sedimentation rate. } \\
\text { Not working after } 6 \text { weeks: referral to } \\
\text { musculoskeletal specialist. } \\
\text { After } 3 \text { months of absence from work: } \\
\text { consultation of multidisciplinary team }\end{array}$ & $\begin{array}{l}\text { If signs suggest a specific or } \\
\text { serious disease. }\end{array}$ & $\begin{array}{l}\text { Identification of chronic pain } \\
\text { syndrome, psychosocial factors } \\
\text { tend to complicate the clinical } \\
\text { problem after } 3 \text { months from the } \\
\text { onset of a spinal disorder. }\end{array}$ & $\begin{array}{l}\text { 0-4 weeks absence from work: } \\
\text { identify work factors that may } \\
\text { have caused the problem. } \\
4-7 \text { weeks absence from work: } \\
\text { assessment of occupational skills } \\
\text { (to assist in returning to work). }\end{array}$ \\
\hline $\begin{array}{l}\text { Australia } \\
\text { (Victoria) }\end{array}$ & $\begin{array}{l}\text { Workers with compensable } \\
\text { LBP }\end{array}$ & $\begin{array}{l}\text { Back pain (non specific). } \\
\text { Back strain (till } 8 \text { weeks after } \\
\text { injury). } \\
\text { Back pain with specific diagnosis. }\end{array}$ & $\begin{array}{l}\text { History. } \\
\text { Physical examination: inspection, palpation } \\
\text { and movements; } \\
\text { signs of nerve root tension and irritation (SLR } \\
\text { etc.); } \\
\text { sign of impairment of nerve conduction } \\
\text { (neurological examination); } \\
\text { functional signs to assess possible } \\
\text { psychological involvement (over-reaction, pain } \\
\text { on simulated force, superficial or } \\
\text { non-anatomical tenderness, regional } \\
\text { weakness or sensory loss, SLR discrepancy); } \\
\text { examination of sacroiliac joints }\end{array}$ & $\begin{array}{l}\text { LBP with no radicular } \\
\text { elements: at } 4 \text { to } 6 \text { weeks } \\
\text { after onset to show individuals } \\
\text { with spondylolysthesis or } \\
\text { degenerative diseases. } \\
\text { Findings must be related to } \\
\text { clinical presentation. } \\
\text { LBP with radicular symptoms } \\
\text { (back and leg pain with } \\
\text { abnormal unilateral signs): at } \\
\text { onset of complaints }\end{array}$ & $\begin{array}{l}\text { Psychosocial history: } \\
\text { circumstances or difficulties at } \\
\text { home and in the workplace, } \\
\text { employment history, previous } \\
\text { workers compensation episodes. } \\
\text { After } 2 \text { and } 6 \text { weeks of absence } \\
\text { from work: psychosocial } \\
\text { assessment, } \\
\text { Assessment of depression, } \\
\text { consider psychological or } \\
\text { psychiatric referral. }\end{array}$ & $\begin{array}{l}\text { Work history: duties, perceived } \\
\text { difficulties in returning to work, } \\
\text { relationships at work. } \\
\text { After } 2 \text { and } 6 \text { weeks of absence } \\
\text { from work: determine need for } \\
\text { vocational assessment. }\end{array}$ \\
\hline USA & $\begin{array}{l}\text { Workers with }<3 \text { months } \\
\text { activity intolerance due to LBP } \\
\text { and/or back related leg } \\
\text { symptoms related to } \\
\text { occupational injury or } \\
\text { exposure }\end{array}$ & $\begin{array}{l}\text { Potentially serious low back } \\
\text { disorders (red flags). } \\
\text { Degenerative disorders. } \\
\text { Non-specific disorders. }\end{array}$ & $\begin{array}{l}\text { Medical history. } \\
\text { Physical examination: general observation, } \\
\text { regional examination of the low back, } \\
\text { neurological screening, testing for } \\
\text { lumbosacral nerve root tension. }\end{array}$ & $\begin{array}{l}\text { When symptoms do not } \\
\text { improve over } 4 \text { weeks, or in } \\
\text { cases of red flags. }\end{array}$ & Not mentioned. & $\begin{array}{l}\text { Perceived work relatedness of } \\
\text { limitations, information on specific } \\
\text { job duties. }\end{array}$ \\
\hline New Zealand & Workers with acute LBP & $\begin{array}{l}\text { Acute (LBP }<3 \text { months) } \\
\text { Recurrent. } \\
\text { Chronic (LBP }>3 \text { months). } \\
\text { Red flags: potentially serious } \\
\text { conditions. } \\
\text { Yellow flags: potential } \\
\text { psychosocial obstacles to } \\
\text { recovery. }\end{array}$ & $\begin{array}{l}\text { History } \\
\text { Screening for red and yellow flags. }\end{array}$ & $\begin{array}{l}\text { Only in cases of "red flags" } \\
\text { or when the symptoms do not } \\
\text { reduce in intensity after } 4 \\
\text { weeks. }\end{array}$ & Screening for yellow flags. & $\begin{array}{l}\text { Identify difficult tasks (heavy work, } \\
\text { lots of lifting and forceful } \\
\text { movements, bending and twisting, } \\
\text { a lot of driving). } \\
\text { Investigate accidents or injuries. }\end{array}$ \\
\hline Netherlands & $\begin{array}{l}\text { Workers who are absent from } \\
\text { work because of LBP }\end{array}$ & $\begin{array}{l}\text { Non-specific LBP. } \\
\text { Radicular syndrome. } \\
\text { Specific LBP. }\end{array}$ & $\begin{array}{l}\text { Medical history. } \\
\text { Physical examination: flexion, extension, } \\
\text { lateral bending and rotation of lower back. } \\
\text { In case of radiation: SLR test, strength, } \\
\text { reflexes, sensibility. }\end{array}$ & $\begin{array}{l}\text { Only in cases of "specific" } \\
\text { LBP }\end{array}$ & $\begin{array}{l}\text { Diagnosis of inadequate pain or } \\
\text { illness behaviour, somatic } \\
\text { fixation, kinesiophobia. }\end{array}$ & $\begin{array}{l}\text { Identify risk factors (twisting, } \\
\text { bending forward and sideward, } \\
\text { frequency of lifting, asymmetric } \\
\text { load). } \\
\text { Eventually assistance of } \\
\text { occupational health nurse or } \\
\text { occupational hygienist for } \\
\text { workplace investigation. } \\
\text { Review psychosocial load of work. }\end{array}$ \\
\hline UK & $\begin{array}{l}\text { Workers presenting with LPB, } \\
\text { and those having difficulty } \\
\text { returning to duties at 4-12 } \\
\text { weeks }\end{array}$ & $\begin{array}{l}\text { Simple back pain. } \\
\text { Nerve root pain. } \\
\text { Red flags for possible serious } \\
\text { spinal pathology. }\end{array}$ & $\begin{array}{l}\text { Screen for serious spinal diseases and nerve } \\
\text { root problems. } \\
\text { Clinical, disability and occupational history. }\end{array}$ & $\begin{array}{l}x \text { ray examinations and scans } \\
\text { not indicated for the } \\
\text { occupational health } \\
\text { management of the worker } \\
\text { with LBP. }\end{array}$ & $\begin{array}{l}\text { Consider psychosocial "yellow } \\
\text { flags"; guidance provided. }\end{array}$ & $\begin{array}{l}\text { Occupational history: concentrate } \\
\text { on impact of symptoms on work, } \\
\text { and any obstacles to recovery and } \\
\text { return to work. }\end{array}$ \\
\hline
\end{tabular}


Table 4 Occupational guidelines: recommendations regarding information and advice, return to work measures, and treatment

\begin{tabular}{|c|c|c|c|}
\hline Country & Information/advice & Return to work measures & Treatment \\
\hline $\begin{array}{l}\text { Canada } \\
\text { (Quebec) }\end{array}$ & $\begin{array}{l}\text { Reassure patient on benign nature of condition and on its compatibility } \\
\text { with work. } \\
\text { Counselling on posture and lifestyle. }\end{array}$ & $\begin{array}{l}\text { If symptoms have improved or do not cause functional restriction, } \\
\text { return to work should be considered. } \\
\text { If after } 3 \text { months the worker has not resumed work a multidisciplinary } \\
\text { team should be consulted (with assistance from the Worker' } \\
\text { compensation board), whose composition will depend on the } \\
\text { underlying problem. }\end{array}$ & $\begin{array}{l}\text { Analgesics, NSAIDs. } \\
\text { Intense pain/spasm: bed rest for } 2 \text { days, prescription renewed if } \\
\text { pain/spasm still intense. } \\
\text { When no improvement: physiotherapeutic modalities including } \\
\text { instruction and practice in proper posture and body mechanics at rest } \\
\text { and during movement. }\end{array}$ \\
\hline $\begin{array}{l}\text { Australia } \\
\text { (Victoria) }\end{array}$ & $\begin{array}{l}\text { Set up a treatment plan, which includes elements of medical treatment } \\
\text { and procedures to facilitate the injured worker's return to work. } \\
\text { Decisions and actions regarding the treatment plan should be fully } \\
\text { discussed with the worker. }\end{array}$ & $\begin{array}{l}\text { A work place visit by the treating practitioner increases the } \\
\text { understanding of the working environment and the available range of } \\
\text { duties. Where possible, return workers to their normal duties. Where } \\
\text { this is not possible, modify their normal tasks. Bring in occupational } \\
\text { rehabilitation services when necessary. }\end{array}$ & $\begin{array}{l}\text { The purpose of treatment is to improve function, with a view to return } \\
\text { to work. } \\
\text { Different treatment options are listed for short term ( } 24 \text { hours to } 6 \\
\text { weeks after injury), medium term ( } 6 \text { to } 12 \text { weeks after injury) and long } \\
\text { term complaints. }\end{array}$ \\
\hline USA & $\begin{array}{l}\text { Provide assurance and education about back problems. } \\
\text { Recommend activity alterations to decrease symptoms. } \\
\text { Encourage return to full activity. }\end{array}$ & $\begin{array}{l}\text { Review of work duties to decide whether modifications can be } \\
\text { accomplished without employer notification and to determine whether } \\
\text { modified duty is available. } \\
\text { Without co-morbidity or complicating factors (employment, legal } \\
\text { issues): maintain patient at maximal levels of activity, including work } \\
\text { activities; target for return to work with modified duty is } 0-2 \text { days; } \\
\text { target for return to work without modified duty is } 7-14 \text { days. }\end{array}$ & $\begin{array}{l}\text { Temporary avoidance of activities that increase mechanical stress on } \\
\text { spine. } \\
\text { Gradual return to normal activities. } \\
\text { Low stress aerobic exercise and conditioning exercises for trunk } \\
\text { muscles after } 2 \text { weeks. } \\
\text { Discussion of surgical option in case of persistent and severe sciatica } \\
\text { and clinical evidence of nerve root compression if symptoms persist } \\
\text { after } 1 \text { month of conservative therapy. }\end{array}$ \\
\hline New Zealand & $\begin{array}{l}\text { LBP usually self-limiting, serious back injuries are not common. } \\
\text { Pain does not mean that work and activity are harmful. } \\
\text { Staying active and at work helps people recover better and more } \\
\text { quickly. } \\
\text { Promote self-management and self-responsibility. }\end{array}$ & $\begin{array}{l}\text { Advice to modify or continue work. } \\
\text { Provide options for modified work tasks and a gradual return to work. } \\
\text { Get occupational advice if needed } \\
\text { Set return to work plan. } \\
\text { Contact between employer, case manager and treatment provider } \\
\text { important. }\end{array}$ & $\begin{array}{l}\text { Advise to continue usual activities and work if appropriate. } \\
\text { Simple pain relief (paracetamol and anti-inflammatory medication). } \\
\text { Manipulation (only in first } 4 \text { to } 6 \text { weeks). } \\
\text { Eventual referral to specialist in case of "red flags". }\end{array}$ \\
\hline Netherlands & $\begin{array}{l}\text { Non specific LBP and lumbosacral radical syndrome (light complaints): } \\
\text { explanation about good prognosis; activity is not harmful. } \\
\text { Lumbosacral radicular syndrome (severe complaints): after treatment, } \\
\text { the above mentioned advice. }\end{array}$ & $\begin{array}{l}\text { Non specific LBP and lumbosacral radical syndrome (light complaints): } \\
\text { return to work within } 2 \text { weeks in absence of complications, adaptation } \\
\text { of duties (hours or tasks) when necessary. } \\
\text { Lumbosacral radicular syndrome (severe complaints): advice on } \\
\text { temporary work adaptation. } \\
\text { Specific LBP: look for acceptable work adaptation in consultation with } \\
\text { employer. }\end{array}$ & $\begin{array}{l}\text { When no improvement within } 2 \text { weeks of work absence: eventual } \\
\text { referral to graded activity programme (gradually increasing exercise } \\
\text { programme). } \\
\text { When no improvement within } 12 \text { weeks of work absence: referral for } \\
\text { multidisciplinary rehabilitation. }\end{array}$ \\
\hline UK & $\begin{array}{l}\text { Employers and workers must be aware that: } \\
\text { - LBP is common and frequently recurrent but acute attacks are usually } \\
\text { brief and self-limiting. } \\
\text { - Physical demands at work are one factor influencing LBP but are } \\
\text { often not the most important. } \\
\text { Case management needs to be directed at both physical and } \\
\text { psychosocial factors } \\
\text { Expected recovery times have to be discussed, as is the importance of } \\
\text { continuing ordinary activities as normally as possible despite pain. } \\
\text { Workers with LBP should receive the key information (The Back Book). }\end{array}$ & $\begin{array}{l}\text { Remain at work or return in early stage even if there is still some LBP. } \\
\text { Advice employers on the actions required, which may include } \\
\text { maintaining sympathetic contact with the absent worker. } \\
\text { Consider temporary adaptation of the job or pattern of work. } \\
\text { Address the common misconception of the need to be pain free } \\
\text { before return to work. } \\
\text { Encourage the employer to establish a surveillance system to identify } \\
\text { those off work with LBP for over } 4 \text { weeks so that appropriate action } \\
\text { can be taken. } \\
\text { Advise employers on ways in which the physical demands of the job } \\
\text { can be temporarily modified to facilitate return to work. }\end{array}$ & $\begin{array}{l}\text { Refer the worker who is having difficulty returning to normal } \\
\text { occupational duties at } 4-12 \text { weeks to an active rehabilitation } \\
\text { programme. } \\
\text { The rehabilitation programme should consist of education, reassurance } \\
\text { and advice, exercise, and pain management according to } \\
\text { behavioural principles; the programme should be embedded in an } \\
\text { occupational setting and strongly directed towards return to work. }\end{array}$ \\
\hline
\end{tabular}


Summary of recommendations for the assessment of LBP

- Diagnostic triage (non-specific LBP, radicular syndrome, specific LBP).

- Exclude "red flags" and neurological screening

- Identify psychosocial factors and potential obstacles to recovery.

- Identify workplace factors (physical and psychosocial) that may be related to the LBP problem and return to work.

- $x$ Ray examinations restricted to suspected cases of specific pathology.

exposure to whole body vibration), accidents or injuries, and perceived difficulties in returning to work or relationships at work. The Dutch and the Canadian guidelines contained recommendations to carry out a workplace investigation ${ }^{10}$ or an assessment of occupational skills when necessary.

\section{Recommendations regarding information and advice, treatment, and return to work strategies}

Most of the guidelines recommended reassuring the employee and providing information about the self limiting nature and good prognosis of LBP. Encouragement of return to ordinary activity as normally as possible was frequently advised.

In line with the recommendation to return to normal activity, all guidelines also stressed the importance of returning to work as rapidly as possible, even if there is still some LBP and if necessary starting with modified duties in more severe cases. Work duties could then be increased gradually (hours and/or tasks), until full return to work was reached. The US and Dutch guidelines provided explicit time schedules for return to work. The Dutch guideline proposed return to work within two weeks with adaptation of duties when necessary. ${ }^{10}$ The Dutch guideline also stressed the importance of time contingent management with regard to return to work. ${ }^{10}$ The US guideline proposed every attempt to maintain the patient at maximal levels of activity, including work activities; targets for disability duration in terms of return to work were given as 0-2 days with modified duties, and 7-14 days if modified duties are not used/available. ${ }^{6}$ In contrast to the others, the Canadian guideline advised return to work only when symptoms and functional restrictions had improved. ${ }^{4}$

In general, the most frequently recommended treatment options in all the included guidelines were: medication for pain relief, ${ }^{58}$ gradually progressive exercise programmes, ${ }^{6}{ }^{10}$ and multidisciplinary rehabilitation. ${ }^{10-13}$ The US guideline recommended referral within two weeks to an exercise programme consisting of aerobic exercises, conditioning exercises for trunk muscles, and exercise quota. ${ }^{6}$ The Dutch guideline recommended that if there is no progress within two weeks of work absence, workers should be referred to a graded activity programme (gradually increasing exercises) and if no progress by four weeks, then to a multidisciplinary rehabilitation programme. $^{10}$ The UK guideline recommended that workers who have difficulty returning to normal occupational duties by 4-12 weeks, should be referred to an active rehabilitation programme. This rehabilitation programme should include education, reassurance and advice, a progressive active exercise and fitness programme, and pain management according to behavioural principles; it should be embedded in an occupational setting and directed strongly towards return to work. ${ }^{11-13}$ Extensive lists of possible treatment options were presented in the guidelines of Canada and Australia, ${ }^{45}$ although most of these were not based on scientific evidence.

\section{DISCUSSION}

The management of LBP in an occupational health setting must address the relation between low back complaints and
Summary of recommendations regarding

information, advice, return to work measures, and treatment in workers with LBP

- Reassure the worker and provide adequate information about the self limiting nature and good prognosis of LBP.

- Advise the worker to continue ordinary activities and working or to return to normal activity and work as soon as possible, even if there is still some pain.

- Most workers with LBP manage to return to more or less normal duties quite rapidly. Consider temporary adaptations of work duties (hours/tasks) only when necessary.

- When a worker fails to return to work within 2-12 weeks (there is considerable variation in the time scale in different guidelines), refer them to a gradually increasing exercise programme, or multidisciplinary rehabilitation lexercises, education, reassurance, and pain management following behavioural principles). These rehabilitation programmes should be embedded in an occupational setting.

work, and develop strategies aimed at a "safe" return to work. This review compared available occupational health guidelines from various countries. Guidelines are rarely indexed in Medline, so when searching for guidelines we had to rely primarily on personal files and personal communication.

\section{Quality aspects and development process of the guidelines}

The assessment by the AGREE instrument ${ }^{3}$ showed some differences in the quality of the guidelines reviewed, which may partly reflect the variation in the dates of development and publication of the guidelines. The Canadian guideline, for example, was published in 1987 and the Australian guideline in $1996 .{ }^{45}$ The other guidelines were more recent and incorporated a more extensive evidence base and more up to date guideline methodology.

Several common flaws related to the development process of the guidelines were shown by the assessment by the AGREE instrument. Firstly, it is important to make clear whether a guideline is editorially independent from the funding body, and whether there are conflicts of interest for the members of the guideline committee. None of the included guidelines clearly reported these issues. Further, reported external review of the guideline by clinical and methodological experts prior to publication was also lacking in all guidelines included in this review.

Several guidelines provided comprehensive information on the way relevant literature was searched and translated into recommendations. ${ }^{4{ }^{11} 13}$ Other guidelines supported their recommendations by references, ${ }^{5} 79^{10}$ but this does not permit assessment of the robustness of the guidelines or their recommendations.

Guidelines depend on the scientific evidence, which changes over time, and it is striking that only one guideline provided for future update. ${ }^{11}{ }^{12}$ Possibly there are updates planned for the other guidelines but they are not explicitly stated (and conversely stating there will be future update does not mean it will actually occur). This lack of reporting may also hold true for other AGREE criteria that we rated negatively. The use of the AGREE framework as a guide for both the development and the reporting of guidelines should help to improve the quality of future guidelines.

\section{Assessment and management of LBP}

The diagnostic procedures recommended in the occupational health guidelines were largely similar to the recommendations of clinical guidelines, ${ }^{2}$ and, logically, the main difference was the emphasis on addressing occupational issues. The reported methods for addressing workplace factors in the assessment of LBP of the individual worker concerned the identification of 
difficult tasks, risk factors, and obstacles for return to work by occupational histories. Obviously, these obstacles for return to work not only concern physical load factors, but also work related psychosocial problems regarding responsibilities, cooperation with co-workers, and the social atmosphere at the workplace. ${ }^{10}$ Screening for work related psychosocial "yellow flags" may help to identify those workers who are at risk for chronic pain and disability. ${ }^{11-13}$

A potentially important feature of the guidelines is that they were consistent regarding their recommendations to reassure the employee with LBP, and to encourage and support return to work even with some persisting symptoms. There is general consensus that most workers do not have to wait until they are completely free of pain before returning to work. The lists of treatment options provided by the Canadian and Australian guidelines may reflect the lack of evidence at that time, ${ }^{45}$ leaving users of the guidelines to choose for themselves. It is, however, questionable whether such lists really contribute to improved care, and in our view guideline recommendations should be based on sound scientific evidence.

The US, Dutch, and UK occupational guidelines ${ }^{6}{ }^{10-13}$ recommend that active multidisciplinary treatment is the most promising intervention for return to work, and this is supported by strong evidence from RCTs. ${ }^{19}{ }^{20}$ However, more research is still needed to identify the optimum content and intensity of those treatment packages..$^{132}$

Despite some evidence for a contribution of workplace factors in the aetiology of $\mathrm{LBP}^{22}$ systematic approaches for workplace adaptations are lacking, and are not offered as recommendations in the guidelines. Perhaps this represents a lack of confidence in the evidence on the overall impact of workplace factors, a difficulty of translation into practical guidance, or because these issues are confounded with local legislation (which was hinted at in the UK guideline ${ }^{11}$ ). It may be that the "participatory ergonomics" intervention, which proposes consultations with the worker, the employer, and an ergonomist, will turn out to be a useful return to work intervention. ${ }^{23}{ }^{24}$ The potential value of "getting all the players onside ${ }^{\prime 25}$ was stressed in the Dutch and the UK guidelines, ${ }^{11-13}$ but further evaluation of this approach and its implementation is required.

\section{Development of future guidelines in occupational health care}

The purpose of this review was to give both an overview and a critical appraisal of occupational guidelines for the management of LBP. The critical appraisal of the guidelines is meant to help direct future development and planned updates of guidelines. In the still emerging field of guideline methodology we consider all past initiatives as laudable; we recognise the need for clinical guidance, and appreciate that guidelines developers cannot wait for research to provide all the methodology and evidence required. However, there is room for improvement and future guidelines and updates should consider the criteria for proper development, implementation, and evaluation of guidelines as suggested by the AGREE collaboration.

The implementation of the guidelines is beyond the scope of this review, but it was noted that none of the guideline documents specifically described implementation strategies, so it is uncertain to what extent the target groups may have been reached, and what effects that may have had. This may be a fruitful area for further research.

The very existence of these occupational health guidelines shows that existing primary care clinical guidelines for $\mathrm{LBP}^{2}$ are considered inappropriate or insufficient for occupational health care. There is a clear perception internationally that the needs of the worker experiencing back pain are intrinsically linked to a variety of occupational issues not covered by usual primary care guidance and, consequently, practice. What emerges is that, despite the methodological flaws, consider- able agreement is evident on a range of fundamental occupational health strategies for managing the worker with back pain, some of which are innovative and challenge previously held views. There is agreement on the fundamental message that prolonged work loss is detrimental, and that early work return should be encouraged and facilitated; there is no need to wait for complete symptom resolution. Although the recommended strategies vary somewhat, there is considerable agreement on the value of positive reassurance and advice, availability of (temporary) modified work, addressing workplace factors ("getting all the players onside"), and rehabilitation for workers having difficulty returning to work.

\section{ACKNOWLEDGEMENTS}

This study was supported by the Dutch Health Care Insurance Council (CVZ), grant DPZ no. 169/0, Amstelveen, Netherlands. J B Staal is currently working at the Department of Epidemiology, Maastricht University, PO Box 6166200 MD Maastricht, Netherlands. W van Mechelen is also part of the Research Centre on Physical Activity, Work and Health, Body@work TNO-VUmc.

\section{Authors' affiliations}

J B Staal, H Hlobil, W van Mechelen, Department of Social Medicine, VU University Medical Centre, Amsterdam, Netherlands

M W van Tulder, Institute for Research in Extramural Medicine, VU

University Medical Centre Amsterdam, van der Boechorststraat 7, 1081

BT Amsterdam, Netherlands

G Waddell, Glasgow Nuffield Hospital, 25 Beaconsfield Road,

Glasgow G12 OPJ, UK

A K Burton, Spinal Research Unit, University of Huddersfield, 30 Queen Street, Huddersfield HDI 2SP, UK

B W Koes, Department of General Practice, Erasmus University Rotterdam, PO Box 1738, 3000 DR Rotterdam, Netherlands

\section{REFERENCES}

1 Van Tulder MW, Koes BW, Bouter LM. A cost-of-illness study of back pain in the Netherlands. Pain 1995;62:233-40.

2 Koes BW, van Tulder MW, Ostelo R, et al. Clinical guidelines for the management of low back pain in primary care: an international comparison. Spine 2001;26:2504-14

3 The AGREE Collaboration. Appraisal of Guidelines Research \& Evaluation Instrument, www.agreecollaboration.org.

4 Spitzer WO, Leblanc FE, Dupuis M. Scientific approach to the assessment and management of activity-related spinal disorders. A monograph for clinicians. Report of the Quebec Task Force on Spinal Disorders. Spine 1987;12(suppl 7S): 1-59.

5 Victorian WorkCover Authority. Guidelines for the management of employees with compensable low back pain. Melbourne: Victorian WorkCover Authority, 1996.

6 Harris JS. Occupational medicine practice guidelines. Beverly, MA: OEM Press, 1997.

7 Accident Compensation Corporation and National Health Committee. Active and working! Managing acute low back pain in the workplace. Wellington, New Zealand, 2000.

8 Accident Compensation Corporation and National Health Committee, Ministry of Health. Patient guide to acute low back pain management. Wellington, New Zealand, 1998.

9 Kendall, Linton SJ, Main CJ. Guide to assessing psychosocial yellow flags in acute low back pain. Risk factors for long-term disability and work loss. Wellington, New Zealand, Accident Rehabilitation \& Compensation Insurance Corporation of New Zealand and the National Health Committee, 1997.

10 Nederlandse Vereniging voor Arbeids- en Bedrijfsgeneeskunde (Dutch Association of Occupational Medicine, NVAB). Handelen van de bedriifsarts bij werknemers met lage-rugklachten. Richtliinen voor Bedriifsartsen. [Dutch guideline for the management of occupational physicians of employees with low back pain]. April 1999.

11 Carter JT, Birell LN. Occupational health guidelines for the management of low back pain at work-principal recommendations. London: Faculty of Occupational Medicine, 2000 (www.facoccmed.ac.uk).

12 Occupational health guidelines for the management of low back pain at work-leaflet for practitioners. London: Faculty of Occupational Medicine, 2000 (www.facoccmed.ac.uk).

13 Waddell G, Burton AK. Occupational health guidelines for the management of low back pain at work-evidence review. Occup Med 2001;51:124-35.

14 Roland M, et al. The back book. Norwich: The Stationery Office, 1996

15 ICSI. Health care guideline. Adult low back pain. Institute for Clinical Systems Integration, 1998 (www.icsi.org/guide/).

16 Kazimirski JC. CMA policy summary: The physician's role in helping patients return to work after an illness or injury. CMA 1997; 156:680A-680C 
17 Yamamoto S. Guidelines on worksite prevention of low back pain. Labour standards bureau notification, No. 57. Industrial Health 1997;35: 143-72.

18 INSERM. Les Lombalgies en milieu professionel: quel facteurs de risque et quelle prevention? [Low back pain at the workplace: risk factors and prevention]. Paris: les editions INSERM, Synthese bibliographique realise a la demande de la CANAM, 2000

19 Lindström I, Ohlund C, Eek C, et al. The effect of graded activity on patients with subacute low back pain: a randomised prospective clinical study with an operant-conditioning behavioural approach. Physical Therapy 1992;72:279-93.

20 Karjalainen K, Malmivaara A, van Tulder M, et al. Multidisciplinary biopsychosocial rehabilitation for subacute low back pain in working-age adults: a systematic review within the framework of the Cochrane Collaboration Back Review Group. Spine 2001;26:262-9.
21 Staal JB, Hlobil $\mathrm{H}$, van Tulder MW, et al. Return-to-work interventions for low back pain: a descriptive review of contents and concepts of working mechanisms. Sports Med 2002;32:251-67.

22 Hoogendoorn WE, van Poppel MN, Bongers PM, et al. Physical load during work and leisure time as risk factors for back pain. Scand J Work Environ Health 1999;25:387-403

23 Loisel P, Gosselin L, Durand P, et al. A population-based, randomised clinical trial on back pain management. Spine 1997;22:2911-18.

24 Loisel P, Gosselin L, Durand P, et al. Implementation of a participatory ergonomics program in the rehabilitation of workers suffering from subacute back pain. App/ Ergon 2001;32:53-60.

25 Frank J, Sinclair S, Hogg-Johnson S, et al. Preventing disability from work-related low-back pain. New evidence gives new hope-if we can just get all the players onside. CMAJ 1998;158:1625-31.

\section{Clinical Evidence-Call for contributors}

Clinical Evidence is a regularly updated evidence based journal available worldwide both as a paper version and on the internet. Clinical Evidence needs to recruit a number of new contributors. Contributors are health care professionals or epidemiologists with experience in evidence based medicine and the ability to write in a concise and structured way.

Currently, we are interested in finding contributors with an interest in the following clinical areas:

Altitude sickness; Autism; Basal cell carcinoma; Breast feeding; Carbon monoxide poisoning; Cervical cancer; Cystic fibrosis; Ectopic pregnancy; Grief/bereavement; Halitosis; Hodgkins disease; Infectious mononucleosis (glandular fever); Kidney stones; Malignant melanoma (metastatic); Mesothelioma; Myeloma; Ovarian cyst; Pancreatitis (acute); Pancreatitis (chronic); Polymyalgia rheumatica; Post-partum haemorrhage; Pulmonary embolism; Recurrent miscarriage; Repetitive strain injury; Scoliosis; Seasonal affective disorder; Squint; Systemic lupus erythematosus; Testicular cancer; Varicocele; Viral meningitis; Vitiligo

However, we are always looking for others, so do not let this list discourage you.

Being a contributor involves:

- Appraising the results of literature searches (performed by our Information Specialists) to identify high quality evidence for inclusion in the journal.

- Writing to a highly structured template (about 2000-3000 words), using evidence from selected studies, within 6-8 weeks of receiving the literature search results.

- Working with Clinical Evidence Editors to ensure that the text meets rigorous epidemiological and style standards.

- Updating the text every eight months to incorporate new evidence.

- Expanding the topic to include new questions once every 12-18 months.

If you would like to become a contributor for Clinical Evidence or require more information about what this involves please send your contact details and a copy of your CV, clearly stating the clinical area you are interested in, to Claire Folkes (cfolkes@bmigroup.com).

\section{Call for peer reviewers}

Clinical Evidence also needs to recruit a number of new peer reviewers specifically with an interest in the clinical areas stated above, and also others related to general practice. Peer reviewers are health care professionals or epidemiologists with experience in evidence based medicine. As a peer reviewer you would be asked for your views on the clinical relevance, validity, and accessibility of specific topics within the journal, and their usefulness to the intended audience (international generalists and health care professionals, possibly with limited statistical knowledge). Topics are usually 2000-3000 words in length and we would ask you to review between 2-5 topics per year. The peer review process takes place throughout the year, and our turnaround time for each review is ideally 10-14 days.

If you are interested in becoming a peer reviewer for Clinical Evidence, please complete the peer review questionnaire at www.clinicalevidence.com or contact Claire Folkes (cfolkes@bmigroup.com). 